\title{
Philosophical and Ideological Basis of European Common Civic Values (on the Example of German Legal Ethics Model)
}

\author{
Kateryna Tkachenko \\ Department of Humanities Sciences Philosophy, Faculty of Philosophy, Taras Shevchenko National University of Kyiv, Kyiv, Ukraine
}

Email address:

ms.katerina@ukr.net

\section{To cite this article:}

Kateryna Tkachenko. Philosophical and Ideological Basis of European Common Civic Values (on the Example of German Legal Ethics Model). International Journal of Philosophy. Vol. 9, No. 1, 2021, pp. 52-59. doi: 10.11648/j.ijp.20210901.14

Received: January 25, 2021; Accepted: February 9, 2021; Published: February 26, 2021

\begin{abstract}
The article deals with the ideological basis, social and cultural features of the formation of European legal and civic values. The value regulations of legal ethics on the example of the formation of the legal culture of Germany are investigated. The author revealed the distinctive character of the Ukrainian socio-cultural context of legal culture from European countries. The study provides tools for understanding and focuses on resolving ethical conflicts in modern advocacy in Ukraine. The author explored the norms of legal ethics adopted in European society, as well as the regulatory potential of deontology through reference to its origins. In the context of social philosophy, the author outlined the ethical potential of due process, the regulatory effect of the value of trust in the legal profession of Germany, as well as revealed the formation of due process and determine its ethical potential. It was concluded that the heuristic potential of the concept of J. Habermas "world community" can be applied to activists of public organizations operating in the modern global world. Such organizations include professional associations of lawyers, which within the UN and the EU conduct regulatory initiatives on the ethical regulation of the professional activities of lawyers. International and regional (EU) bar associations are organizations of the world community that are engaged in ethical rulemaking in relation to the professional activity of lawyers. Regulatory principles of this type of organizations are mandatory in the scope of their action.
\end{abstract}

Keywords: Civil Society, Law, Morality, Values, Deontology, Humanism, Justice, Legal Ethics

\section{Introduction}

The ideological basis for the formation of European civic values, in our opinion, are the contractual theories of the New Age, when in the European socio-cultural space was set a general value orientation to legal norms. This is how the socio-cultural features of European society, its politics and law are formed.

The philosophical thought of the theory of natural law substantiates the natural nature of law, its moral principles and contractual basis, inextricably linking morality and law. Such theories have created an axiological, ethical and philosophical basis for the development of legal ethics as a value-imperative regulation of lawyers, politicians and statesmen.

Thus, the general value orientation to the legal norms of the European socio-cultural space with a projection on the global world was set under the influence of modern contractual theories, and in the twentieth century it defined a common space of legal values of the UN and the EU.

In this article, we will explore the norms of legal ethics adopted in European society, as well as the regulatory potential of deontology through reference to its origins.

In the context of social philosophy, we will explore the ethical potential of due process, the regulatory effect of the value of trust in the legal profession of Germany, as well as reconstruct the formation of due process and determine its ethical potential.

\section{Literature Review}

In his treatise "To Eternal Peace" I. Kant outlined the civil status, where civil society on a global scale guarantees equal rights to each of its members. It is known that in the twentieth century Kant's idea was the basis of a common space of legal 
values of the United Nations and the European Union.

More than two centuries have passed since I. Kant wrote the treatise "To Eternal Peace", in which a prominent thinker among the issues of international relations and international law outlined the world civil status, a voluntary union of states, where civil society guarantees equal rights to each member. At the same time, Kant considers the "union of peoples", "federalism of free states" an association of this type, which preserves the national sovereignty of each of them, and does not mean the introduction of a world power [1].

This Kant's text became discussed and was perceived as a guide in international relations, setting the horizon of the ideological search. Therefore, it is natural that to some extent Kant's provisions were the basis for the formation of first the League of Nations, then the United Nations, as well as the values of the European Union.

J. Habermas, working on the text of the dissertation "Structural transformations in the field of openness" [2], introduces the concept of "world community".

In his political works, J. Habermas wrote a lot about the value and normative principles of UN unification in the light of Kant's concept. He notes the key role of Kant in formulating the ideas of world citizenship and supranational entities. "Kant introduces a third dimension in the theory of law: along with state law and international law - and this has entailed important consequences the right of universal citizenship" [3]. The thinker points to the benefits of this condition and the consequences that are obvious today.

For Habermas, the political culture of the public is connected with the idea of law and is "the ground on which the institutions of freedom are rooted, and at the same time is the environment where the growth of political civilization of the population" [4].

Habermas's view on the political and legal foundations in different European countries and their cultural and historical features is interesting. In the context of the formation of civil society under the influence of contractual theories, when the origins of law were contractual relations between the ruling classes of early modern times (nobility, church and cities) and the king... formed the concept of "constitution", which indicates the limitation of political domination through distributive distribution of branches of power. This idea, embodied in the oldest parliaments or caste assemblies, adapted to collective representation, the idea of mutual limitation and balancing of "dominant forces", in modern theories of the state developed into the idea of distributive, distributive, "separation of powers", "separation of sovereign power".; it was combined with individualistic concepts - the doctrine of human rights in English liberalism; on the functional separation of legislative, executive and law in German constitutionalism. Thus arise the idea of the restrictive arbitrariness of power "rule of law" - "rule of law" and "rule of law" [5].

At the same time, the modern researcher N. Motroshilova believes that Habermas defends a subtle and special opinion here: in substantiating the concept of "eternal" peace, Kant still gives the palm of supremacy to the right principle, although he does not deny that they can act alongside it. and considerations of morality "[6]. And although this course of thought of Habermas Motroshilova explains the specific political circumstances and the need to give them their assessment [7], the general tone of Habermas' thoughts is obvious - it determines the legal basis of civil society of the Union of Nations.

Well-known researcher and lawyer Eugene Ehrlich in his work "Montesquieu and Sociological Jurisprudence" believed that law depends on many different conditions and changes immediately with these conditions. In Montesquieu's works, Ehrlich read that law is a form of social life, indirectly absorbing natural circumstances (geographical location, landscape, climate) and depends on religion, principles of government, customs, etc. [8].

The value regulations of legal ethics on the example of the formation of the legal culture of Germany were studied in detail by a modern researcher of law and the history of law in Western countries S. Dekhanov [9].

Also, the problem of philosophical and ideological basis of European common civic values was represented in recent studies devoted to the judicial practice. Amid them we would like to outline the results obtained by M. Kolesnikova's [10] and O. Vasylchenko's [11] research groups.

\section{Results and Discussion}

For a deeper understanding of the topic, let us explore the idea of the relationship between law and morality in the global world, which Habermas deduces from the law of world citizenship. The thinker opposes substituting the provisions of positive (living) law with purely moral arguments, referring to Kant's ideas of eternal peace: "The idea of a world-civil order that guarantees the" unification of all peoples under the auspices of public law "becomes" true". imperative, not just a temporary state of peace. This conceptual connection of the body of peace to the legal principle explains the "world-civil" goal of the philosophy of history" [12].

At the same time, the philosopher points to the failures of Kant's project on a global scale. The ineffectiveness of Kant's idea of the union of peoples Habermas shows by the example of the UN Charter. Designed to act as a global regulator, the $\mathrm{UN}$ has no binding force on individual governments, can not encourage these governments to a lawful course of action, because the same Charter prohibits interference in the internal affairs of an independent state [13].

Habermas: "The community of nations must be able, by threatening sanctions, at least to motivate its members to a lawful course of action. Only in this way an unstable system of self-asserting sovereign states, based on mutual threats, becomes a federation with common institutions that assume state functions: to regulate the connection of members of the federation with each other and monitor compliance with the relevant rules" [14].

In a world of global shifts, the global community has already come to the fore during the wars in Vietnam and the Persian Gulf; it organized environmental conferences in Rio 
de Janeiro under the auspices of the United Nations, on poverty in Copenhagen, on climate, and so on. "We can perceive these meetings as we perceive the same numerous attempts due to the mere thematization in the world community of problems important for the survival of mankind, due to the appeal to world public opinion at least to exert some political pressure on governments... However, the central role that new types of organizations, namely non-governmental organizations, play not only at such conferences, but also in the creation and mobilization of national forms of society in general, is a sign of the growing journalistic influence of actors who seem to stand in the way of states. to the whole world of civil society" [16].

One of these organizations, associations at the level of the world community, can rightly include associations of lawyers, which within the UN conduct regulatory initiatives at the global level. After all, the value burden of a lawyer's activity depends on his affiliation with professional associations, which are guided in their activities by proper legal procedures.

Based on a number of international instruments (such as the Universal Declaration of Human Rights (1948), the International Covenant on Civil and Political Rights (1966), the International Covenant on Economic, Social and Cultural Rights (1966) and a number of others), The European Bar Association defines the parameters for the proper protection of human rights and fundamental freedoms to which all persons are entitled, whether economic, social and cultural, or civil and political, and provides for effective access to the legal services provided. independent legal profession.

As early as 1950, the European Convention for the Protection of Human Rights and Fundamental Freedoms was adopted at the European level. It distinguished between the right to legal representation and the right to defense. The first concerned the scope of civil rights and obligations, and the second - guarantees of presumption of innocence and minimum procedural protection [17]. Subsequently, in 1988, in order to maintain high standards of professional practice for lawyers, a "Common Code of Rules for Advocates of the European Community" was developed and adopted by a delegation of twelve participating countries at a plenary session in Strasbourg. It can be noted here that the requirements declared by Habermas to ensure and respect human rights and freedoms, intolerance of violations of these requirements, have become a common value of modern Europe, and therefore were reflected in regional (EU) regulations.

This document in its humanistic orientation is aimed at defenders. It emphasizes the special socially significant role of a lawyer, explains the essence of the rules of professional ethics, their voluntary nature and binding force. A lawyer in the European Community "must act in the interests of the law as a whole, as well as in the interests of those whose rights and freedoms are entrusted to him. The lawyer is entrusted with a set of obligations, both legal and moral, which often come into conflict with each other and can be divided into the following categories: obligations to the client; obligations to the court and other authorities; obligations to colleagues; obligations to society" [18].

Modern researcher of law and history of advocacy in Western countries S. O. Dekhanov believes that "Member States of the European Union have an obligation to bring domestic legislation in line with regulations adopted at the European level" [19], and they actively implement legislative initiatives into national legislation.

S. Dekhanov points out that the modern period of development of Western European advocacy is characterized, on the one hand, by a great variety of manifestations of its individual institutions (models of advocacy self-government, organizational and legal forms of advocacy, attitude to advocacy monopoly), and on the other - universal features and characteristics" [20].

Instead, the scholar emphasizes, the constitutional and legal status of the bar is determined by the very idea of the rule of law and fundamental human rights, "but often, unlike the right to protection and legal aid, the bar does not have a constitutional basis." [21]

Determining the socio-cultural features of lawyer ethics in Germany is of scientific interest by combining national traditions of law and the ability of the EU, in which Germany is one of the leading countries to regulate law in a complex social life.

But first it is necessary to outline the historical circumstances of the formation of ethical regulation of the legal profession in Germany. According to S. Dekhanov, the first mention of the bar in Germany dates back to the VI century, when the laws of the Lombards and Visigoths began to appear under different names, lawyers-defenders. Since the courts were established, the client's interests have been allowed to be represented, but ethical standards, such as the obligation to keep confidential information obtained from principals, have not been established. However, counsel was prohibited from simultaneously defending or advising both parties in the proceedings, as well as testifying about the cases of trustees.

From the Middle Ages to the beginning of the XIX century there were no significant changes in the position of representatives. "Until 1800 in Germany (Germany as part of the Holy Roman Empire of the German nation) there were a variety of positions, professions, roles, persons who provided legal assistance: commissioners of justice, lawyers, prosecutors. In 1879 , as a result of the adoption of a single status of the German Bar, the old names were replaced and replaced by a single name - lawyer (Rechtsanwalt)" [22].

From 1532 to 1877 , the activities of lawyers were regulated by the norms of the general criminal law of the "Carolina" [23], according to which the duties of the defense counsel included "assisting the court in finding the truth; to act in this regard together with the judges and to inform the judges in full detail of everything that becomes known to them in the case, without any consideration as to which party it is harmful or useful" [24]. With such an understanding of the role and tasks of defenders in society, there could be no legislative regulation of the confidentiality of the relationship between a lawyer and a principal. This had a negative impact on the protection of 
citizens' rights and on justice in general. According to P. Korotkova, "this state of affairs leads to the need to improve existing legislation" [25].

With changes, the Statute of Criminal Procedure of 1877 existed until 1959, when the "Federal Regulation on the Bar" was adopted. This document deals with ethical principles in $\S 43$, which states in particular: "A lawyer must perform his work in good faith. His actions must be worthy of the respect and trust required by the status of a lawyer both within and outside his professional activity" [26]. These formulations were clarified in later editions, namely in $\S 43 \mathrm{a}$, which regulates the duties of a lawyer, such as defending the independent status of a lawyer, maintaining legal secrecy, observance of business conduct and use of professional vocabulary in work, avoiding conflicts of interest, the obligation to improve their skills during professional activities.

The value of trust mentioned in the Federal Regulation deserves attention. One of the key values of public life in modern times, it has repeatedly become the subject of special attention in the social philosophy of modern times. Trust is "a complex hierarchical social formation that reflects a certain value relationship, which has the character of expecting the desired result of potentially uncontrolled interactions and is based on confidence in the correctness and effectiveness of the object of trust, recognizing its activities as meeting certain ethical requirements" [27]. This general definition makes it possible to understand why trust and fulfillment of promises have become the subject of special attention in the philosophy of J. Locke, Hume, I. Kant in the perspective of the foundations of social order. As the American sociologist A. Seligman points out, today such searches mean an institutional or system-forming component of trust, an attempt to assert social institutions on something that is outside of them. "Trust is something that enters into social relations, when there is an opportunity to deviate from the roles, what may be called" open spaces of roles and role expectations" [28].

In the above-mentioned document, the value of trust is presented at the individual level - as a role expectation of a representative of the profession, which can be trusted by the client. But the institutional level is also important - such as public trust in the bar in general, which works to increase the level of trust in society as a whole.

The requirements that society places on future lawyers are important. The Law on the Judiciary prescribes requirements that are common to both future lawyers and judges. The ministry of the land where the person plans to obtain the profession of lawyer makes a request to the bar association at the place of his internship. The members of the commission must make a careful review of the activities of the applicant, which takes into account his personal qualities. In addition, there is a list of conditions under which a lawyer cannot carry out his professional activity. They apply to both applicants and legal practitioners, namely: (1) loss of basic civil rights in connection with a decision of a constitutional court; (2) a formal ban on holding public office; (3) exclusion from the bar; (4) dismissal from law enforcement agencies by decision of a disciplinary court; (5) committing an act that is unworthy of legal status; (6) combating the existing social order illegally; (7) loss of ability to perform their professional duties for a long period of time due to physical disabilities or spiritual weakness; (8) the existence of a double life or ancillary activities incompatible with the legal profession; (9) restrictions on the right to dispose of their property, etc. [28]. Obviously, these requirements are based on the value of trust how society can trust those who choose the profession of lawyer.

German law seeks to avoid ethical contradictions regarding the dishonesty of lawyers within the "corporation". To this end, specialized courts have been created, "courts of honor", as these instances in society are called, which are within the jurisdiction of local judicial bodies. "Courts of honor" as independent of the legal community make decisions on the disciplinary liability of lawyers. Members of the "courts of honor" are appointed by the Ministry of Justice for four years and work on a voluntary basis. All cases are heard by the full Court and decisions are taken collectively. Judgments in lawyers' cases are harsh. In addition to reprimands and fines for a significant amount compared to the average salary of a lawyer, the board may impose a ban on advocacy for one to five years or be expelled from the bar altogether. Appeals are authorized to be considered by a special court chamber at the Supreme Court of each state and the Senate for Advocacy, which is subordinate to the Supreme Federal Court. The members of the Judicial Chamber are judges and highly qualified lawyers with many years of practice and impeccable reputation. The Chamber is also not completely independent. Each of its verdicts is tested for integrity and impartiality by the Senate for Advocacy [29].

To understand the possibilities of ethical regulation of the lawyer in the light of modern conflicts, due to the specifics of today's public demands, it is necessary to turn to the institution of legal secrecy. Legal secrecy gives the legal profession an exceptional position in the professional space, uniting the figure of a lawyer with a doctor and a priest. "Legal secrecy is a part of public order, has a general character, absolute and unlimited in time. Due to his status, a lawyer becomes a client's proxy, so the implementation of legal secrecy is in the public interest. Legal secrecy is the right and duty of a lawyer. The right and obligation to maintain legal secrecy apply to everything that became known to the lawyer during the execution of the power of attorney, and continue to be kept after the execution of the power of attorney" [30].

Legal secrecy is directly based on the value of trust in its individual and institutional dimensions. "The object of legal secrecy is such an unconditional, essential and necessary social good as the immunity of the principal, ie the special legal status of the inviolability of the rights and interests of the principal in connection with recourse to a lawyer and legal aid" [31]. According to Dekhanov, today the situation in Western Europe regarding the preservation of legal secrecy is being questioned due to the constant doubtfulness of the actions of clients and their lawyers, then covered by the right to legal secrecy. 
In light of this problem, Germany's position is remarkable. It depends entirely on society's recognition of trust as a fundamental ethical value. In this regard, it is worth quoting the views of the famous American sociologist F. Fukuyama on the cultural values of the Germans, which he expressed in the book "Trust". Defining the role of trust as a universal characteristic of culture in the formation of the country's well-being, Fukuyama devoted a separate section to clarifying the principles of organization of public life in Germany. As a national trait of the Germans, Fukuyama called, in addition to the tendency to discipline, the love of "playing by the rules", which strengthens the sense of belonging to his cultural group [32].

Germany has consistently advocated a strict position of absolute secrecy within the "lawyer-client". Even in the case of an accusation of belonging to a terrorist organization [33], the restriction of the client's correspondence with a lawyer cannot be considered an exception to this principle, as "lawyer's mail" cannot be handed over to a judge without the client's consent. If the client does not give such consent, the mail is not passed to a lawyer and is subject to disposal without disclosing the information available there. Thus, personal correspondence between a lawyer and a client cannot be disclosed by law enforcement under any circumstances. The judge in charge of checking the correspondence has a whole list of reservations. He may not conduct an investigation even on behalf of him and may not disclose to the investigation any information which has become known to him from these letters. Even a client accused of a serious crime has the right to a relationship of trust with his or her lawyer, in which the state can only intervene as an "observer" with the most limited functions and means of influence. A clear example of such an order of things is the case "Niemietz v. Germany ", which was heard in 1992 by the European Court of Human Rights [34].

Lawyer M. Nimitz, a citizen of Germany, for some time held the position of chairman of the local political party "Bunte liste" ("Bright List"), some members of which also participated in the anti-clerical working group. At the end of 1985, a judge of the city of Freiburg, where the organization was located, received a letter signed by an anti-clerical group and named Klaus Wegner. The letter contained threats based on the judge's "pro-clerical" attitude to the criminal case, which was being heard in the local court at the time. In August 1996, the judge obtained a search warrant for the Bunte liste office, where documents could be found that would shed light on the identity of Klaus Wegner. The search did not reveal any clues to the investigation, the criminal proceedings were closed due to lack of evidence and due to the exhaustion of the term of consideration. Nimetz's personal belongings were kept in the party's office, including personal correspondence with clients and documents, the announcement of which could reveal information that is subject to legal secrecy. This was the reason for Nimetz's lawsuit. In his opinion, the search was carried out without sufficient legal grounds. In Germany, this appeal was rejected by both the First Land Court of Munich and the Federal Constitutional Court, which argued that the search had already taken place, so that no legal interest could be established in the act declaring the search illegal. Nimetz moved the case to the international level, appealing in 1988 to the Commission of the European Court of Human Rights. He appealed that his right to respect for housing and correspondence had been violated, [34] leaving him without legal remedies within his own state. In 1992, the European Court upheld the claim of M. Nimetz's lawyer, confirming that the search had been carried out outside the ethical and legal norms of the society: "Taking into account the nature of the materials in question, it is clear that the search infringed on professional secrecy. given the circumstances; in this connection, it should be recalled that the invasion of a lawyer's professional secrecy may have consequences for the administration of justice and thereby infringe the rights guaranteed by Article 6 of the Convention. In addition, the accompanying publicity could have a negative effect on the applicant's professional reputation in the eyes of both his clients and the general public." [34]

This case set a paradigm for professional secrecy, which was reflected in the further development of legal ethics in Germany. For 10 years, the European Court of Human Rights has heard the case "Erdem v. Germany" [35], which showed a completely different attitude of society to these issues. The court ruled that in the conditions of ensuring the right of the state to protect its citizens from terrorism, interference in the personal correspondence of a lawyer with a client could be only very limited, and oral communication could not be regulated in any way and should take place freely, without interfering with their trust relationship. Unlawful interference with legal secrecy or interference without sufficient grounds must provide for liability, as reflected in German criminal law.

However, it is worth mentioning a number of conditions under which a lawyer has the right to disclose professional secrecy between him and the client: if the information becomes publicly available and officially published (for example, in the state register or in the press); if the client appeals in court against the amount of the lawyer's fee; in the case of a criminal trial against a lawyer [28].

In 2010, the Congress of Advocates discussed another condition - the release of the lawyer's own client from the need to maintain secrecy. However, the analysis of such situations revealed that such practices can harm the client, the lawyer, as well as third parties.

Thus, it is obvious that the fundamental value of legal ethics in Germany is the value of trust. Built into the ethical infrastructure in national legal regulations governing the legal profession in Germany, trust is given at the individual level, defining role expectations from the lawyer and allowing the client to feel confident, and determines stability at the institutional level, enabling public trust in potentially uncontrolled interactions of modern complex society. The institution of legal secrecy is based on the value of trust in both the individual and institutional dimensions. Absolute observance of legal secrecy is evidence of a society with a high level of trust and at the same time a guarantee of support from professionals and society as a whole trust in this 
institution, which works to maintain and increase the level of trust in society.

At the same time, the President of the Federal Bar Association of Germany, W. Horrer, noted the bureaucratization and legalization of all spheres of human life as problems. This, on the one hand, pushes lawyers to increase specialization, and on the other - does not allow to ignore the processes of integration into the single space of the EU, which leads to streamlining and consolidation of a single system of codes and regulations governing lawyers in the EU [36]. The Law on the Practice of European Lawyers in Germany in 2000 quite scrupulously regulates the conditions for the practice of professional law by EU lawyers in Germany [37]. The directives on which the Law is based, with the consent of the EU member states, are transposed into their domestic legislation, and thus the legal regulation in these countries is closer in wording to the German one.

Building on the values of the new Europe, a number of international instruments prescribing the rules of conduct for lawyers have been adopted in recent years. Among them, the International Lawyers' Standards for the Independence of the Legal Profession (1990) and the Charter of Basic Principles for the European Bar (2006) are the most important.

The Specialized Commission of Advocates of the European Union - the Deontological Committee - has prepared documents on normative provision and regulation of ethical activity of a lawyer, in which it updates the principles existing in previous documents in accordance with modern legal practice, based on certain precedents and decisions of the European Court of Human Rights. Here are some of the latest documents that are most indicative in ethical terms: Statement of lawyers of the European Union on professional secrecy as a lawyer's professional privilege (2017) [38]; On providing protection against information leakage (2017) [39]; Proposals from European Union lawyers: Draft report of the Committee on Civil Liberties, Justice and Home Affairs of the European Parliament with the Commission's recommendations on the establishment of an EU mechanism in the field of democracy, rule of law and fundamental rights (2016) [40]; Response of European Union lawyers to the European Commission's public online consultation on increasing corporate tax transparency (2015) [41].

Thus, the institution of legal secrecy is based on the value of trust in the individual and institutional dimensions. Absolute observance of legal secrecy is evidence that a society in which such a practice exists has a high level of trust. At the same time, the support of professionals and society as a whole for the absolute observance of legal secrecy is a guarantee of trust in it, which works to maintain and increase the level of trust in society.

\section{Conclusions}

Thus, the heuristic potential of the concept of J. Habermas "world community" can be applied to activists of public organizations operating in the modern global world. Such organizations include professional associations of lawyers, which within the UN and the EU conduct regulatory initiatives on the ethical regulation of the professional activities of lawyers. International and regional (EU) bar associations are organizations of the world community that are engaged in ethical rulemaking in relation to the professional activity of lawyers. Regulatory principles of this type of organizations are mandatory in the scope of their action.

At the same time, speaking of the unity of Europe and outlining the components of European identity, even a supporter of a single European space, such as Habermas, is forced to state that Britain and the Scandinavian countries do not maintain a friendly attitude to the European constitution, at least at government level. Today, after Brexit, it is obvious that ordinary citizens have also spoken out against excessive integration, so the adoption of a single constitution has been postponed indefinitely. Habermas states with sadness that the EU's political and legal space has never become homogeneous [42].

The main reason can be considered that the EU was formed without taking into account the cultural and historical characteristics of its member countries. The history of each country is unique, so the conditions for the formation, development of the legal profession and the field of problems that are on the agenda are unique.

All countries belonging to the leading European states have little in common in the history of law and civil society, due to differences in historical progress in general and the conditions of their formation, in which it is only possible to talk about the institution of law.

Thus, there is no reason to talk about the homogeneity of the legal field, which necessitates the consideration of cultural and historical experience as a factor in the regulatory potential of legal ethics in the social and cultural context.

The study provides tools for understanding and focuses on resolving ethical conflicts in modern advocacy in Ukraine.

\section{References}

[1] Gulyga A. V. (1977). Kant. Moscow. p. 237. (in Russian language).

[2] Habermas J. (2000). Structural transformations in the field of openness. Lviv: (in Russian language).

[3] Habermas J. (2001). Involvement of another. Essays on political theory. St. Petersburg. p. 277. (in Russian language).

[4] Habermas J. (2001). Involvement of another. Essays on political theory. St. Petersburg, p. 294 (in Russian language).

[5] Habermas J. (2008). Split West. Moscow, p. 127-128 (in Russian language).

[6] Motroshilova N. V. (2010). Civilization and Barbarism in the Age of Global Crisis: 2nd, expanded and corrected edition of the book "Civilization and Barbarism in the Modern Age". Moscow, p. 317 (in Russian language).

[7] Motroshilova N. V. (2010). Civilization and Barbarism in the Age of Global Crisis: 2nd, expanded and corrected edition of the book "Civilization and Barbarism in the Modern Age". Moscow, p. 316 (in Russian language). 
[8] Ehrlich E. (2014). Montesquieu and sociological jurisprudence. Chernivtsi: Scientific Bulletin of Chernivtsi University. Vol. 32, p. 6-7 (in Ukrainian language).

[9] Dekhanov S. A. (2010). Advocacy in Western Europe: experience and current state. Moscow (in Russian language).

[10] Kolesnikova, M., Kiselyova, E., Vasylchenko, O., Svyrydova, L., \& Kibets, D. (2020). Judicial Practice as a Pre-Condition for Preventing Contradictory Judicial Decisions. Journal of Legal, Ethical and Regulatory Issues, 23 (5). Retrieved from https://www.abacademies.org/articles/judicial-practice-as-a-pr econdition-for-preventing-contradictory-judicial-decisions-96 99.html

[11] Vasylchenko, O., Lotiuk, O., \& Gut, N. (2018). Civil society as the subject of formation of state policy in the sphere of subsoil use and protection. Naukovyi Visnyk Natsionalnoho Hirnychoho Universytetu, (6), 118-123. doi: 10.29202/nvngu/2018/20.

[12] Habermas J. (2008). Split West. Moscow, p. 110-111 (in Russian language).

[13] Habermas J. (2001). Involvement of another. Essays on political theory. St. Petersburg, p. 297-298 (in Russian language).

[14] Habermas Y. (2001). Involvement of another. Essays on political theory. St. Petersburg, p. 297 (in Russian language).

[15] Habermas J. (2001). Involvement of another. Essays on political theory. St. Petersburg, p. 293-294 (in Russian language).

[16] Dekhanov S. A. (2010). Advocacy in Western Europe: experience and current state. Moscow, p. 26. (in Russian language).

[17] Dekhanov S. A. (2010). Advocacy in Western Europe: experience and current state. Moscow, p. 26-27 (in Russian language).

[18] Dekhanov S. A. (2010). Advocacy in Western Europe: experience and current state. Moscow, p. 41 (in Russian language).

[19] Dekhanov S. A. (2010). Advocacy in Western Europe: experience and current state. Moscow, p. 4 (in Russian language).

[20] Dekhanov S. A. (2010). Advocacy in Western Europe: experience and current state. Moscow, p. 11 (in Russian language).

[21] Dekhanov S. A. (2010). Advocacy in Western Europe: experience and current state. Moscow, p. 23 (in Russian language).

[22] Carolina (2002). Extract from the Criminal Code of Charles V: Textbook. Moscow: Moscow Academy of the Ministry of Internal Affairs of Russia (in Russian language).

[23] Pestrzhetsky A. A. (1876). About the Roman Bar, in France and in Germany. Moscow: University Printing House (Katkov) on Strastny Boulevard, p. 88 (in Russian language).

[24] Korotkova P. E. (2009). Formation and development of the institute of legal secrecy in Ancient Germany. Kyiv: Journal of the Bar Academy of Ukraine. Vol. No. 9, p. 3. (in Ukrainian language).

[25] Federal Regulations on Advocacy. 1959. Retrieved from: http://unba.org.ua/assets/uploads/legislations/pologennya/bun desrechtsanwaltsordnung-ukr.pdf (in Ukrainian language).

[26] Kozhemyakina O. M. (2012). Ethical context of trust as a value basis of social interaction. Collection of scientific articles: Social ethics: theoretical and applied problems. Kyiv: University of Ukraine, p. 25 (in Ukrainian language).

[27] Seligmen A. (2002). The problem of trust. Moscow, p. 21 (in Russian language).

[28] Tkachenko K. O. (2017). Principles of legal ethics in modern Germany. Collection "Gileya: scientific bulletin". Vol. 124 (September), p. 237-240 (in Ukrainian language).

[29] Dekhanov S. A. (2010). Advocacy in Western Europe: experience and current state. Moscow, p. 15 (in Russian language).

[30] Dekhanov S. A. (2010). Advocacy in Western Europe: experience and current state. Moscow, p. 40 (in Russian language).

[31] Fukuyama F. (2004). Trust: social virtues and the path to prosperity. Moscow, p. 342 (in Russian language).

[32] Strafprozeßordnung in der Fassung der Bekanntmachung vom 7 April 1987 (BGBl. I S. 1074, 1319), die zuletzt durch Artikel 2 des Gesetzes vom 17. July 2017 (BGB1. I S. 2442) geändert worden ist. Retrieved from: https://www.gesetze-im-internet.de/stpo/StPO.pdf.

[33] Niemietz v. Germany. (2018). 72/1991/324/396, Council of Europe: European Court of Human Rights. - 16 December 1992. Retrieved from: http://www.refworld.org/cases,ECHR,3f32560b4.html.

[34] European Court of Human Rights. - Council of Europe. F-67075. - Strasbourg cedex. Retrieved from: www.echr.coe.int.

[35] Erdem v. Germany. (2001). № 38321/97, § 46, ECHR 2001-VII. The European Court of Human Rights. Strasbourg, 5 July $2001 \quad$ Retrieved from: https://www.legal-tools.org/doc/4a2597/pdf.

[36] Report of the Executive Director of the FPA of Germany Veronica Horrer at the Round Table on "Specialization of Lawyers" with the participation of representatives of the Federal Bar Association of Germany and the Federal Chamber of Advocates of the Russian Federation. (03.12.2015). Retrieved from: http://fparf.ru/documents/doc/Spezialisierung\%20der\% 20RA Russisch\% 20 (\% D0\% BF\% D0\% B5\% D1\% 80\% D0\% B5\% $\overline{\mathrm{D}} 0 \% \mathrm{~B} 2 \% \mathrm{D} 0 \% \mathrm{BE} \% \mathrm{D} 0 \%$ B4).pdf.

[37] Humphries M. (November 30, 2009). Legal ethics, past and present - part two. The Law Society Gazette. Retrieved from: https://www.lawgazette.co.uk/analysis/legal-ethics-past-and-p resent-part-two/53308.article.

[38] CCBE Statement on professional Secrecy/ legal professional privilege (LPP). (15/09/2017). Council of Bars and Law Societies of Europe. Retrieved from: http://www.ccbe.eu/fileadmin/speciality_distribution/public/d ocuments/DEONTOLOGY/DEON_Postion_Papers/EN_DEO N_20170915_Statement-on-professional-secrecy_LPP.pdf.

[39] Submission on whistle-blowing protections. (19/05/2017). Council of Bars and Law Societies of Europe. Retrieved from: http://www.ccbe.eu/fileadmin/speciality_distribution/public/d ocuments/DEONTOLOGY/DEON_Postion_Papers/EN_DEO N_20170519_Submission-on-whistleblower-protection.pdf. 
[40] CCBE proposals. European Parliament Committee on Civil Liberties, Justice and Home Affairs Draft Report with recommendations to the Commission on the establishment of an EU mechanism on democracy, the rule of law and fundamental rights. (20/05/2016). Council of Bars and Law Societies of Europe. Retrieved from: http://www.ccbe.eu/fileadmin/speciality_distribution/public/d ocuments/DEONTOLOGY/DEON_Postion_Papers/EN_DEO N 20160520_CCBE_Proposals_Rules_of_Law merchanism. pdf.
[41] CCBE response to the online public consultation of the European Commission on further corporate tax transparency (08/09/2015). Council of Bars and Law Societies of Europe. Retrieved from: http://www.ccbe.eu/fileadmin/speciality distribution/public/d ocuments/DEONTOLOGY/DEON_Postion_Papers/EN_DEO N_20150908_CCBE_Response_Corporate_taxation.pdf.

[42] Habermas J. (2012). Oh, Europe. Small political works. Moscow, p. 101-102 (in Russian language). 